\title{
The Kappa Opioid Receptor is required for some intermittent alcohol drinking induced changes in stress and threat responding in male C57BL/6J mice
}

\author{
Lara S. Hwa ${ }^{a}$, , Morgan Bowling ${ }^{a}$, Rachel Calloway ${ }^{a}$, Thomas L. Kash ${ }^{a, b, c}$ \\ aBowles Center for Alcohol Studies, 'Department of Pharmacology, University of North Carolina \\ at Chapel Hill, 104 Manning Drive, Chapel Hill, NC, 27599, USA
}

Corresponding Author:

Thomas L. Kash, Ph.D.

John R. Andrews Distinguished Professor

Bowles Center for Alcohol Studies

Department of Pharmacology

University of North Carolina School of Medicine

Chapel Hill, NC 27599, USA

tkash@email.unc.edu

(919)843-7867 

available under aCC-BY-NC-ND 4.0 International license.

\section{Highlights}

- Intermittent alcohol drinking changed stress reactions in mice.

- KOR antagonist norBNI altered some, but not all, stress responses in alcohol drinkers 


\begin{abstract}
The dynorphin/kappa opioid receptor (KOR) system in the brain regulates both stressful experiences and negative, aversive states during withdrawal from drugs of abuse. We explored the role of this system during acute withdrawal from long-term alcohol drinking. Male C57BL/6J mice were subjected to repeated forced swim tests, home cage exposure to a predator odor, and a visual threat after intermittent access to alcohol or water. Systemic injection of KOR antagonist norBNI reversed alcohol-related differences in immobility time during the second swim test and reduced burying behavior in response to predator odor, but did not affect behavioral response to visual threat.
\end{abstract}

\title{
Key Words
}

Intermittent access to alcohol, forced swim stress, TMT, predator odor, looming disc, norBNI, dynorphin, kappa opioid receptor,mice. 


\section{Abbreviations}

Alcohol use disorder (AUD), alcohol $(\mathrm{EtOH})$, water $\left(\mathrm{H}_{2} \mathrm{O}\right)$, preprodynorphin (Pdyn), trimethylthiazoline (TMT), forced swim stress (SS), non-stress (NS), kappa opioid receptor

$(\mathrm{KOR})$, baseline $(\mathrm{BL})$, norbinaltorphimine (norBNI), bed nucleus of the stria terminalis (BNST), phosphate buffer solution (PBS), tyramine signal amplification (TSA).

\section{Acknowledgements}

This work was supported by the National Institutes of Health [grant numbers K99AA027576 (LSH) and U01AA020911 (TLK) 


\section{Introduction}

The endogenous dynorphin/kappa opioid receptor (KOR) system is a regulator of stress responses and anxiety-like behavior (Bruchas, Land, and Chavkin 2010). Dynorphin/KOR signaling has also been heavily studied for treating negative symptomology observed in alcohol dependence (Walker et al. 2012; Kharkhanis et al. 2017). Rats rendered alcohol dependent with ethanol vapor show anxiety-like behavior during acute withdrawal, including decreased time spent in the open arm of the elevated plus maze, increased $22 \mathrm{kHz}$ ultrasonic vocalizations, and increased marble burying, all of which can be blocked with the KOR antagonist norbinaltorphimine (norBNI, Valdez and Harshberger 2012, Berger et al. 2013, Rose et al. 2016). In this study, we sought to determine how alcohol drinking could impact multiple stress related behavioral responses and determine if the KOR was involved.

\section{Materials and Methods}

\subsection{Animals}

We used adult male C57BL/6J mice (Jackson Laboratories, Bar Harbor, ME) for behavioral pharmacology experiments with norBNI and Pdyn shRNA. Mice were singly housed in polycarbonate cages (GM500, Tecniplast, Italy) on a 12:12-h reversed dark-light cycle with lights off at 7:00am. Mice had ad libitum rodent chow (Prolab Isopro RMH 3000, LabDiet, St. Louis, MO) and $\mathrm{H}_{2} \mathrm{O}$. The UNC School of Medicine Institutional Animal Care and Use Committee approved all protocols. Experiments were conducted in accordance with the NIH Guidelines for the Care and Use of Laboratory Animals.

\subsection{Intermittent EtOH Drinking}

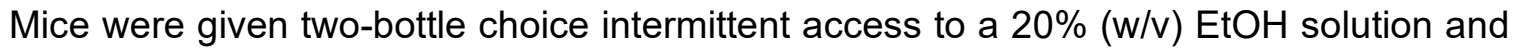
water for at least 6 weeks (Hwa et al. 2011, Hwa et al. 2020). Drinking tubes positioned through 
customized cage lids consisted of conical centrifuge tubes (Catalog No. 05-502-10B; ThermoFisher) with rubber stopper (size 5.5, Ancare) and sippers (OT-101, 3.5 inch, Ancare). Bottles were weighed before and after 24 hour EtOH access on Mondays, Wednesdays, and Fridays. Fluid loss due to handling was averaged each week from a dummy cage and was subtracted from each mouse's daily consumption. Mice were weighed to calculate daily EtOH intake in grams/kilogram $(\mathrm{g} / \mathrm{kg})$. Daily EtOH preference was defined as the ratio of EtOH fluid consumed divided by the total fluid $\left(\mathrm{EtOH}\right.$ plus $\left.\mathrm{H}_{2} \mathrm{O}\right)$ consumed.

\subsection{Forced Swim Stress}

After EtOH drinking, mice were exposed to two episodes of swim stress (SS) according to the protocol described by Anderson, Lopez, and Becker (2016). Mice were placed in $22-24^{\circ} \mathrm{C}$ water in a $20.32(w) \times 26.67(h) \mathrm{cm}$ acrylic cylinder for $10 \mathrm{~min} 4 \mathrm{hr}$ before EtOH access. After each swim test, mice were dried and a heat lamp was kept over the home cage. There was one drinking day in between the double swim trial days (e.g. Monday and Friday swim stress preceding EtOH access on Monday, Wednesday, and Friday; Fig 1A). Latency to immobility and duration of immobility were recorded for both trials.

\subsection{TMT Predator Odor}

After repeated swim tests, mice were tested for their behavioral responses to the predator odor trimethylthiazoline (TMT) during acute, 6-8 hour, withdrawal from EtOH drinking [Fig 1A]. Testing occurred under 15-20 lux dim lighting conditions in a separate, ventilated room with a fume hood. After a $10 \mathrm{~min}$ habituation to a cotton tip applicator placed in the corner of the home cage (baseline, BL), $2.5 \mu \mathrm{TMT}$ (BioSRQ) was applied to the cotton tip followed by 10 min of behavioral testing. We have previously characterized that C57BL/6J male mice display a repertoire of stress-related and exploratory behaviors during the home cage TMT test, such as 
burying, freezing, grooming, rearing, stretch-attend, and walking (Hwa et al. 2020). Among these behaviors, burying represents a canonical stress or defensive-like behavioral state in rodents (Pinel and Treit 1978, De Boer and Koolhaas 2003). Durations of seconds 1) burying, 2) in contact with the TMT, and 3) in the far corners of the cage, were recorded and quantified with Ethovision XT13 (Noldus, The Netherlands). Percent change from the baseline was quantified for time spent in contact with the object and spent in the far corners, and raw increase in burying behavior in sec was measured from the pre-trial baseline.

\subsection{Looming disc}

After TMT exposure, mice were tested for reactions to an overhead looming disc during 6-8 hr withdrawal from intermittent EtOH [Fig 1A]. Based off of the protocol described by Yilmaz and Meister (2013), we used a custom open field chamber (48 x $48 \times 30 \mathrm{~cm})$ with three matte walls and one transparent wall for observation. One strip of red infrared LED lights provided ambient light in the test box, and an infrared camera (Basler GigE) recorded testing. A wide computer monitor (HP 22es, $48 \mathrm{~cm}$ ) spanned across the test chamber to display the overhead looming disc animation. A triangular prism-shaped protective hut $(12 \times 20 \mathrm{~cm})$ was positioned in the back corner during habituation and testing. Mice were placed into the test chamber for $10 \mathrm{~min}$ habituation to the arena, the protective hut, and the overhead monitor displaying a grey background (RGB 128, 128, 128). The looming disc animation was triggered when the mouse moved across the center of the arena after the $10 \mathrm{~min}$ habituation. The animation consisted of a $0.5 \mathrm{sec}$ solid black circle rapidly increasing in size, repeated 15 times. In reaction to the looming disc, freezing behavior $(\mathrm{s})$, maximum velocity $(\mathrm{cm} / \mathrm{s})$ of the dart, and the escape distance $(\mathrm{cm})$ were recorded and quantified by Ethovision XT13.

\subsection{NorBNI testing}


Five mg/kg norBNI (Cat no. 0347, Tocris) was administered i.p., 1ml/100g, $16 \mathrm{hr}$ before the second forced swim test to both $\mathrm{EtOH}$ and $\mathrm{H}_{2} \mathrm{O}$ mice. We have previously reported this time point for norBNI pretreatment to minimized handling stress prior to the stress reactivity testing and allowed for KOR antagonism (Hwa et al. 2020) instead of non-specific mu opioid antagonism that occurs initially post-injection (Endoh et al. 1992). Importantly, norBNI is known for its ultralong duration of action (Munro et al. 2012). Since published reports have shown behavioral effects of norBNI for up to 86 days post-injection (Potter et al. 2011), it is likely that norBNI was on board during the second forced swim test, the TMT test, and the looming disc assay.

\subsection{Statistical Analyses}

Statistical tests were analyzed with GraphPad Prism 8 (La Jolla, CA, USA). Mixed model ANOVA was used to analyze immobility time and latency to immobility across Trials (Swim I and Swim II) between Drinking groups $\left(\mathrm{H}_{2} \mathrm{O}\right.$ and $\left.\mathrm{EtOH}\right)$. For TMT testing with norBNI or Pdyn-shRNA knockdown, two-way ANOVA was run to analyze contact with TMT, time spent in the far corners, and burying with Drug (no injection and norBNI) and Drinking as factors. Two-way ANOVA were similarly run for effects of norBNI on looming disc responses such as freezing, maximum velocity, and escape distance.

\section{Results}

\subsection{Kappa opioid receptor regulation of alcohol-related responses to repeated swim test and predator odor}

After a long-term history of voluntary EtOH drinking, mice were tested in three different stress and threat-related assays compared to single-housed, $\mathrm{H}_{2} \mathrm{O}$-drinking controls [Fig 1A]. 
Adult male C57BL/6J mice escalated their daily alcohol consumption $(\mathrm{g} / \mathrm{kg})$ and alcohol preference on the intermittent, two-bottle choice schedule for 8 weeks [Fig 1B-C].

In the repeated forced swim test, $\mathrm{H}_{2} \mathrm{O}$-drinking controls increased their immobility time from the first to the second swim, suggestive of learned stress coping responses, whereas EtOH drinkers did not [Fig 1D; Main effect of Trial $F(1,15)=5.466, p=0.0337$; Main effect of Drinking $\mathrm{F}(1,15)=22.61, \mathrm{p}=0.003$; Swim I $\mathrm{H}_{2} \mathrm{O}$ vs Swim II $\mathrm{H}_{2} \mathrm{O} \mathrm{t}(15)=4.494, \mathrm{p}=0.0009$; Swim II $\mathrm{H}_{2} \mathrm{O}$ vs Swim II EtOH $\mathrm{t}(30)=2.933, \mathrm{p}=0.0127]$. In a separate group of mice, norBNI administration caused an increase in immobility time in the $\mathrm{EtOH}$ mice, implying a norBNI rescue of EtOH-impaired responding [Fig 1E; Main effect of Drinking $\mathrm{F}(1,13)=36.60$, $\mathrm{p}<0.001$; Swim I $\mathrm{H}_{2} \mathrm{O}$ vs Swim II $\mathrm{H}_{2} \mathrm{O}$ $\mathrm{t}(13)=4.170, \mathrm{p}=0.0022$; Swim I EtOH vs Swim II EtOH $\mathrm{t}(13)=4.398, \mathrm{p}=0.0014]$. Latency to immobility decreased from the first to the second swim [Fig 1F; Main effect of Trial $F(1,15)=41.79$, p<0.001; Swim I $\mathrm{H}_{2} \mathrm{O}$ vs Swim II $\mathrm{H}_{2} \mathrm{O}$ t(15)=4.489, $\mathrm{p}=0.0009$; Swim I EtOH vs Swim II EtOH $t(15)=4.663, p=0.0006$ ]; however, EtOH history was not a factor. Latency to immobility was not affected by norBNI [Fig 1G; Main effect of Trial $F(1,26)=59.29, p<0.001$; Swim I $\mathrm{H}_{2} \mathrm{O}$ vs Swim II $\mathrm{H}_{2} \mathrm{O} \mathrm{t}(26)=4.887, \mathrm{p}<0.0001$; Swim I EtOH vs Swim II EtOH t(26)=6.047, $\left.\mathrm{p}<0.0001\right]$.

Next, mice were tested for their responses to TMT predator odor in the home cage. While TMT avoidance was maintained in $\mathrm{H}_{2} \mathrm{O}$ controls compared to non-odor baseline, norBNI decreased high levels of TMT contact in the EtOH mice [Fig 1H, Main effect of Drinking $F(1,30)=5.950, p=0.0209$; Main effect of Drug $F(1,30)=5.438, p=0.0266$; no injection $\mathrm{H}_{2} \mathrm{O}$ vs no injection $\mathrm{EtOH} t(30)=2.933, p=0.0377$; no injection $\mathrm{EtOH}$ vs norBNI EtOH t(30)=2.919, $\mathrm{p}=0.0390$ ]. Contact with the novel object during the no-odor baseline revealed an interaction between the factors, but post-hoc differences were not significant [Fig $1 \mathrm{H}$ left inset, Drinking x Drug Interaction $F(1,30)=6.577, p=0.0156]$. During the test, norBNI reduced time spent contacting the TMT in $\mathrm{EtOH}$ mice [Fig 1H right inset, Main effect of Drinking $F(1,30)=4.255, p=0.0479$; Main effect of Drug $F(1,30)=5.530, p=0.0255$; no injection $E t O H$ vs norBNI EtOH $t(30)=1.697, p=0.049]$. NorBNI additionally increased percent change from baseline time spent in the far corners in EtOH mice 
[Fig 1I, Main effect of Drinking $F(1,30)=8.880, p=0.0057$; no injection EtOH vs norBNI EtOH $t(30)=2.954, p=0.0357]$. There were no EtOH or norBNI effects on raw time spent in the far corners in either the baseline period or the TMT test [Fig 1/ left and right inset]. TMT-induced burying as a function of baseline increased with norBNI treatment in $\mathrm{EtOH}$ mice [Fig 1J, Main effect of Drinking $F(1,30)=10.38, p=0.0031$; no injection $\mathrm{EtOH}$ vs norBNI EtOH $\mathrm{t}(30)=3.491, \mathrm{p}=0.0090]$. Minimal burying activity during the baseline was different for norBNI-injected $\mathrm{H}_{2} \mathrm{O}$ mice and noninjected EtOH mice [Fig 1J left inset, Main effect of Drinking $F(1,30)=8.811, p=0.0058$; norBNI $\mathrm{H}_{2} \mathrm{O}$ vs no injection EtOH $t(30)=3.192, p=0.0197$ ]. Burying behavior in response to TMT was reduced in $\mathrm{EtOH}$ mice, which was restored in $\mathrm{EtOH}$ mice by norBNI pretreatment [Fig $1 \mathbf{J}$ right inset, Main effect of Drinking $F(1,30)=12.06, p=0.0016$; Main effect of Drug $F(1,30)=5.950$, $p=0.0208$; no injection $\mathrm{H}_{2} \mathrm{O}$ vs no injection EtOH $\mathrm{t}(30)=3.281, \mathrm{p}=0.0156$; no injection EtOH vs norBNI EtOH t(30)=3.932, $\mathrm{p}=0.0028]$.

Third, mice were assessed for reactions to the overhead looming disc. EtOH mice spent less time than controls freezing upon looming disc presentation, but norBNI did not affect these reactions in either group [Fig 1 K, Main effect of Drinking $F(1,30)=9.659, p=0.0041$ ]. Further, EtOH mice had a heightened maximum velocity $(\mathrm{cm} / \mathrm{s})$ of the escape dart to the protective hut, but norBNI did not alter this response [Fig 1L, Main effect of Drinking $F(1,30)=18.53, p=0.0002$; norBNI $\mathrm{H}_{2} \mathrm{O}$ vs norBNI EtOH t(30)=3.538, $\left.\mathrm{p}=0.0080\right]$. The escape distance $(\mathrm{cm})$ was overall farther for EtOH mice compared to $\mathrm{H}_{2} \mathrm{O}$ mice, but again, norBNI treatment was not a factor [Fig $1 \mathbf{M}$, Main effect of Drinking $\mathrm{F}(1,30)=4.215, \mathrm{p}=0.0489]$.

\section{Discussion}

Here, we found that KOR antagonist norBNI altered $\mathrm{EtOH}$-induced disruptions in a repeated forced swim test and exposure to predator odor, but did not change reactions to a looming disc. Alcohol driven reductions in response to stress have been well-studied in humans (Sher 1987), so we aimed to determine how alcohol consumption could alter stress- and threat- 
related phenotypes in male C57BL/6J mice. In the forced swim test, $\mathrm{EtOH}$ and $\mathrm{H}_{2} \mathrm{O}$ mice showed no differences in immobility duration or latency to immobility in the forced swim test after eight weeks intermittent $\mathrm{EtOH}$ drinking. Others have also reported no differences in first swim test immobility between controls and EtOH mice after chronic intermittent EtOH vapor or ip EtOH injections at various withdrawal time points (Ribeiro-Carvalho et al. 2011, Bray et al. 2017, Maldonado-Devincci et al. 2016). There has been a resurgence in behavioral interpretation of the rodent forced swim test; besides anti-depressive-like behavior, immobility can also be interpreted as stress coping behavior, especially during repeated trials (Commons et al. 2017, Molendijk and De Kloet 2019). In agreement with this literature, we interpret the subsequent increase in immobility time during the second swim trial as a learned adaptive state, to conserve energy resources by staying immobile, which was evident in $\mathrm{H}_{2} \mathrm{O}$ controls but not in EtOH drinkers. This bears some superficial similarity to the immobility observed in $\mathrm{H}_{2} \mathrm{O}$ controls in response to the overhead looming disc. In contrast, EtOH mice exhibited much less immobility in favor of immediate darting behavior, suggestive of hyperresponsivity and differential assessment of the overhead threat. These reactions were accompanied by a longer escape path, which we additionally consider maladaptive in reaction to descending threat.

We also tested mice in their home cage for avoidance and burying responses to the predator odor TMT. EtOH mice generally showed increased contact with the TMT and reduced burying, which we have shown persists into protracted abstinence (Hwa et al. 2020). Defensive burying is a prominent stress coping strategy when rodents are confronted with noxious stimuli (De Boer and Koolhaas 2003), suggesting altered coping strategy. Taken together, these results suggest a history of EtOH drinking may alter stress and threat responses. Many others have observed EtOH withdrawal impairments in anxiety-like behavior in classical tests such as: deficits in social interactions (File et al. 1989, Lowery-Gionta et al. 2015, Marcinkiewcz et al. 2015), elevated plus maze (Lal et al. 1991; Wilson et al. 1998), elevated zero maze and light-dark test (Kliethermes et al. 2004) and novelty-induced hypophagia (Pang et al. 2013, Sidhu et al. 2018). 
In addition, it was found that intermittent $\mathrm{EtOH}$ consumption led to increased sensitivity to social defeat stress (Nenning et al. 2020). These 'affective disturbances' during withdrawal (Holleran et al. 2016) may be also caused by slowed learning or low cognitive flexibility after intermittent EtOH exposure (Sey et al. 2019). Future studies should investigate stress-related cognitive impairment or behavioral flexibility in more formal tasks of decision making.

Comparing our TMT-evoked stress reactions to others, some have reported increased digging activity in 10-day withdrawal from chronic intermittent EtOH vapor (Sidhu et al. 2018), but this discrepancy may be explained by differential performance in the familiar home cage in response to TMT versus spontaneous digging activity in a novel cage. The Bains group, however, found decreased home cage digging after acute footshock stress (Füzesi et al. 2016), which is similar to the current results in EtOH-exposed mice after TMT. Our findings in the looming disc assay compliment the increased defensive responses to the bottle brush defined as increased escaping, which may be related to irritability or aggression found during withdrawal (Sidhu et al. 2018, Hwa et al. 2015.)

The present experiments have limitations. In the behavioral pharmacology studies, we acknowledge there is no vehicle injection group. As we were exploring subtle differences in stress behavior, we employed a non-injected, baseline behavioral strategy instead. Concerns for norBNI not being on board during stress testing are mitigated by the fact that systemic norBNI lasts for months post-injection (Potter et al. 2011).Another consideration worth discussing is the repeated stress tests. It is plausible that the repeated forced swim tests affected the TMT behavioral tests

\section{References}

Al-Hasani, R., McCall, J. G., Shin, G., Gomez, A. M., Schmitz, G. P., Bernardi, J. M., ... \& Krashes, M. J. (2015). Distinct subpopulations of nucleus accumbens dynorphin neurons drive aversion and reward. Neuron, 87(5), 1063-1077. 
Anderson, R. I., Lopez, M. F., \& Becker, H. C. (2016). Forced swim stress increases ethanol consumption in C57BL/6J mice with a history of chronic intermittent ethanol exposure. Psychopharmacology, 233(11), 2035-2043.

Berger, A. L., Williams, A. M., McGinnis, M. M., \& Walker, B. M. (2013). Affective cue-induced escalation of alcohol self-administration and increased $22-\mathrm{kHz}$ ultrasonic vocalizations during alcohol withdrawal: role of kappa-opioid receptors. Neuropsychopharmacology, 38(4), 647-654.

Bloodgood, D. W., Hardaway, J. A., Stanhope, C. M., Pati, D., Pina, M. M., Neira, S., ... \& Kash, T. L. (2020). Kappa opioid receptor and dynorphin signaling in the central amygdala regulates alcohol intake. Molecular psychiatry, 1-13.

Bradford, D. E., Shapiro, B. L., \& Curtin, J. J. (2013). How bad could it be? Alcohol dampens stress responses to threat of uncertain intensity. Psychological science, 24(12), 2541-2549.

Bray, J. G., Roberts, A. J., \& Gruol, D. L. (2017). Transgenic mice with increased astrocyte expression of CCL2 show altered behavioral effects of alcohol. Neuroscience, 354, 88-100.

Bruchas, M. R., Land, B. B., \& Chavkin, C. (2010). The dynorphin/kappa opioid system as a modulator of stress-induced and pro-addictive behaviors. Brain research, 1314, 44-55.

Bruchas, M. R., Land, B. B., Aita, M., Xu, M., Barot, S. K., Li, S., \& Chavkin, C. (2007). Stress-induced p38 mitogen-activated protein kinase activation mediates k-opioid-dependent dysphoria. Journal of Neuroscience, 27(43), 11614-11623.

Bruchas, M. R., Land, B. B., Lemos, J. C., \& Chavkin, C. (2009). CRF1-R activation of the dynorphin/kappa opioid system in the mouse basolateral amygdala mediates anxiety-like behavior. PloS one, 4(12), e8528.

Campbell, R. R., Domingo, R. D., Williams, A. R., Wroten, M. G., McGregor, H. A., Waltermire, R. S., ... \& Quadir, S. G. (2019). Increased alcohol-drinking induced by manipulations of mGlu5 phosphorylation within the bed nucleus of the stria terminalis. Journal of Neuroscience, 39(14), 2745-2761.

Centanni, S. W., Morris, B. D., Luchsinger, J. R., Bedse, G., Fetterly, T. L., Patel, S., \& Winder, D. G. (2019). Endocannabinoid control of the insular-bed nucleus of the stria terminalis circuit regulates negative affective behavior associated with alcohol abstinence. Neuropsychopharmacology, 44(3), 526-537.

Chavkin, C. (2018). Kappa-opioid antagonists as stress resilience medications for the treatment of alcohol use disorders. Neuropsychopharmacology, 43(9), 1803-1804.

Ch'ng, S., Fu, J., Brown, R. M., McDougall, S. J., \& Lawrence, A. J. (2018). The intersection of stress and reward: BNST modulation of aversive and appetitive states. Progress in NeuroPsychopharmacology and Biological Psychiatry, 87, 108-125.

Cohen, A., Whitfield, T. W., Kreifeldt, M., Koebel, P., Kieffer, B. L., Contet, C., ... \& Koob, G. F. (2014). Virus-mediated shRNA knockdown of prodynorphin in the rat nucleus accumbens attenuates depression-like behavior and cocaine locomotor sensitization. PLoS One, 9(5), e97216.

Commons, K. G., Cholanians, A. B., Babb, J. A., \& Ehlinger, D. G. (2017). The rodent forced swim test measures stress-coping strategy, not depression-like behavior. ACS chemical neuroscience, 8(5), 955-960. 
Crowley, N. A., Bloodgood, D. W., Hardaway, J. A., Kendra, A. M., McCall, J. G., Al-Hasani, R., ... \& Lowell, B. B. (2016). Dynorphin controls the gain of an amygdalar anxiety circuit. Cell reports, 14(12), 27742783.

Dao, N. C., Suresh Nair, M., Magee, S. N., Moyer, J. B., Sendao, V., Brockway, D. F., \& Crowley, N. A. (2020). Forced Abstinence from Alcohol Induces Sex-Specific Depression-like Behavioral and Neural Adaptations in Somatostatin Neurons in Cortical and Amygdalar Regions. Frontiers in Behavioral Neuroscience, 14, 86.

Daviu, N., Füzesi, T., Rosenegger, D. G., Rasiah, N. P., Sterley, T. L., Peringod, G., \& Bains, J. S. (2020). Paraventricular nucleus $\mathrm{CRH}$ neurons encode stress controllability and regulate defensive behavior selection. Nature Neuroscience, 23(3), 398-410.

De Boer, S. F., \& Koolhaas, J. M. (2003). Defensive burying in rodents: ethology, neurobiology and psychopharmacology. European journal of pharmacology, 463(1-3), 145-161.

Endoh, T., Matsuura, H., Tanaka, C., \& Nagase, H. (1992). Nor-binaltorphimine: a potent and selective kappa-opioid receptor antagonist with long-lasting activity in vivo. Archives internationales de pharmacodynamie et de therapie, 316, 30-42.

Erikson, C. M., Wei, G., \& Walker, B. M. (2018). Maladaptive behavioral regulation in alcohol dependence: Role of kappa-opioid receptors in the bed nucleus of the stria terminalis. Neuropharmacology, 140, 162-173.

Fellinger, L., Jo, Y. S., Hunker, A. C., Soden, M. E., \& Zweifel, L. S. (2020). A midbrain dynorphin circuit promotes threat generalization. bioRxiv.

File, S. E., Baldwin, H. A., \& Hitchcott, P. K. (1989). Flumazenil but not nitrendipine reverses the increased anxiety during ethanol withdrawal in the rat. Psychopharmacology, 98(2), 262-264.

Füzesi, T., Daviu, N., Cusulin, J. I. W., Bonin, R. P., \& Bains, J. S. (2016). Hypothalamic CRH neurons orchestrate complex behaviours after stress. Nature communications, 7, 11937.

Giardino, W. J., Eban-Rothschild, A., Christoffel, D. J., Li, S. B., Malenka, R. C., \& de Lecea, L. (2018). Parallel circuits from the bed nuclei of stria terminalis to the lateral hypothalamus drive opposing emotional states. Nature neuroscience, 21(8), 1084-1095.

Gorka, S. M., \& Shankman, S. A. (2017). Preliminary evidence that reactivity to uncertain threat is an endophenotype for alcohol use disorder. Drug and alcohol dependence, 180, 265-271.

Gorka, S. M., Lieberman, L., Phan, K. L., \& Shankman, S. A. (2016). Association between problematic alcohol use and reactivity to uncertain threat in two independent samples. Drug and Alcohol Dependence, 164, 89-96.

Haun, H. L., Griffin, W. C., Lopez, M. F., \& Becker, H. C. (2020). Kappa opioid receptors in the bed nucleus of the stria terminalis regulate binge-like alcohol consumption in male and female mice. Neuropharmacology, 167, 107984.

Holleran, K. M., Wilson, H. H., Fetterly, T. L., Bluett, R. J., Centanni, S. W., Gilfarb, R. A., ... \& Winder, D. G. (2016). Ketamine and MAG lipase inhibitor-dependent reversal of evolving depressive-like behavior during forced abstinence from alcohol drinking. Neuropsychopharmacology, 41(8), 20622071. 
Hwa, L. S., Chu, A., Levinson, S. A., Kayyali, T. M., DeBold, J. F., \& Miczek, K. A. (2011). Persistent escalation of alcohol drinking in C57BL/6J mice with intermittent access to $20 \%$ ethanol. Alcoholism: Clinical and Experimental Research, 35(11), 1938-1947.

Hwa, L. S., Nathanson, A. J., Shimamoto, A., Tayeh, J. K., Wilens, A. R., Holly, E. N., ... \& Miczek, K. A. (2015). Aggression and increased glutamate in the mPFC during withdrawal from intermittent alcohol in outbred mice. Psychopharmacology, 232(16), 2889-2902.

Hwa, L. S., Neira, S., Flanigan, M. E., Stanhope, C. M., Pina, M. M., Pati, D., ... \& Boyt, K. (2020). Alcohol drinking alters stress response to predator odor via BNST kappa opioid receptor signaling in male mice. Elife, 9, e59709.

Hwa, L. S., Neira, S., Pina, M. M., Pati, D., Calloway, R., \& Kash, T. L. (2019). Predator odor increases avoidance and glutamatergic synaptic transmission in the prelimbic cortex via corticotropinreleasing factor receptor 1 signaling. Neuropsychopharmacology, 44(4), 766-775.

Jarman, S. K., Haney, A. M., \& Valdez, G. R. (2018). Kappa opioid regulation of depressive-like behavior during acute withdrawal and protracted abstinence from ethanol. PloS one, 13(9), e0205016.

Karkhanis, A., Holleran, K. M., \& Jones, S. R. (2017). Dynorphin/kappa opioid receptor signaling in preclinical models of alcohol, drug, and food addiction. In International Review of Neurobiology (Vol. 136, pp. 53-88). Academic Press.

Kash, T. L., Baucum, A. J., Conrad, K. L., Colbran, R. J., \& Winder, D. G. (2009). Alcohol exposure alters NMDAR function in the bed nucleus of the stria terminalis. Neuropsychopharmacology, 34(11), 2420-2429.

Kasten, C. R., Carzoli, K. L., Sharfman, N. M., Henderson, T., Holmgren, E. B., Lerner, M. R., ... \& Wills, T. A. (2020). Adolescent alcohol exposure produces sex differences in negative affect-like behavior and group I mGluR BNST plasticity. Neuropsychopharmacology, 1-10.

Kim, J. S., Han, S. Y., \& Iremonger, K. J. (2019). Stress experience and hormone feedback tune distinct components of hypothalamic CRH neuron activity. Nature communications, 10(1), 1-15.

Kissler, J. L., Sirohi, S., Reis, D. J., Jansen, H. T., Quock, R. M., Smith, D. G., \& Walker, B. M. (2014). The one-two punch of alcoholism: role of central amygdala dynorphins/kappa-opioid receptors. Biological psychiatry, 75(10), 774-782.

Kliethermes, C. L., Cronise, K., \& Crabbe, J. C. (2004). Anxiety-like behavior in mice in two apparatuses during withdrawal from chronic ethanol vapor inhalation. Alcoholism: Clinical and Experimental Research, 28(7), 1012-1019.

Lal, H., Prather, P. L., \& Rezazadeh, S. M. (1991). Anxiogenic behavior in rats during acute and protracted ethanol withdrawal: reversal by buspirone. Alcohol, 8(6), 467-471.

Land, B. B., Bruchas, M. R., Schattauer, S., Giardino, W. J., Aita, M., Messinger, D., ... \& Chavkin, C. (2009). Activation of the kappa opioid receptor in the dorsal raphe nucleus mediates the aversive effects of stress and reinstates drug seeking. Proceedings of the National Academy of Sciences, 106(45), 19168-19173.

Le Merrer, J., Becker, J. A., Befort, K., \& Kieffer, B. L. (2009). Reward processing by the opioid system in the brain. Physiological reviews, 89(4), 1379-1412. 
Lê, A. D., Funk, D., Coen, K., Tamadon, S., \& Shaham, Y. (2018). Role of k-opioid receptors in the bed nucleus of stria terminalis in reinstatement of alcohol seeking. Neuropsychopharmacology, 43(4), 838-850.

Lowery-Gionta, E. G., Marcinkiewcz, C. A., \& Kash, T. L. (2015). Functional alterations in the dorsal raphe nucleus following acute and chronic ethanol exposure. Neuropsychopharmacology, 40(3), 590600.

Mague, S. D., Pliakas, A. M., Todtenkopf, M. S., Tomasiewicz, H. C., Zhang, Y., Stevens, W. C., ... \& Carlezon, W. A. (2003). Antidepressant-like effects of K-opioid receptor antagonists in the forced swim test in rats. Journal of Pharmacology and Experimental Therapeutics, 305(1), 323-330.

Maldonado-Devincci, A. M., Kampov-Polevoi, A., McKinley, R. E., Morrow, D. H., O'Buckley, T. K., \& Morrow, A. L. (2016). Chronic intermittent ethanol exposure alters stress effects on (3a, 5a)-3-

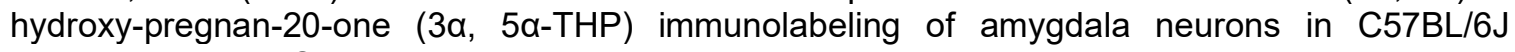
mice. Frontiers in Cellular Neuroscience, 10, 40.

Marcinkiewcz, C. A., Dorrier, C. E., Lopez, A. J., \& Kash, T. L. (2015). Ethanol induced adaptations in 5HT2c receptor signaling in the bed nucleus of the stria terminalis: implications for anxiety during ethanol withdrawal. Neuropharmacology, 89, 157-167.

McElligott, Z. A., Klug, J. R., Nobis, W. P., Patel, S., Grueter, B. A., Kash, T. L., \& Winder, D. G. (2010). Distinct forms of Gq-receptor-dependent plasticity of excitatory transmission in the BNST are differentially affected by stress. Proceedings of the National Academy of Sciences, 107(5), 22712276 .

McLaughlin, J. P., Marton-Popovici, M., \& Chavkin, C. (2003). k opioid receptor antagonism and prodynorphin gene disruption block stress-induced behavioral responses. Journal of Neuroscience, 23(13), 5674-5683.

Molendijk, M. L., \& de Kloet, E. R. (2019). Coping with the forced swim stressor: current state-of-the-art. Behavioural Brain Research, 364, 1-10.

Munro, T. A., Berry, L. M., Van't Veer, A., Béguin, C., Carroll, F. I., Zhao, Z., ... \& Cohen, B. M. (2012). Long-acting $\mathrm{K}$ opioid antagonists nor-BNI, GNTI and JDTic: pharmacokinetics in mice and lipophilicity. BMC pharmacology, 12(1), 5.

Nennig, S. E., Fulenwider, H. D., Eskew, J. E., Whiting, K. E., Cotton, M. R., McGinty, G. E., ... \& Schank, J. R. (2020). Intermittent ethanol access increases sensitivity to social defeat stress. Alcoholism: Clinical and Experimental Research, 44(3), 600-610.

Normandeau, C. P., Suárez, M. T., Sarret, P., McElligott, Z. A., \& Dumont, E. C. (2018). Neurotensin and dynorphin Bi-Directionally modulate CeA inhibition of oval BNST neurons in male mice. Neuropharmacology, 143, 113-121.

Pang, T. Y., Renoir, T., Du, X., Lawrence, A. J., \& Hannan, A. J. (2013). Depression-related behaviours displayed by female C57BL/6J mice during abstinence from chronic ethanol consumption are rescued by wheel-running. European Journal of Neuroscience, 37(11), 1803-1810.

Pati, D., Marcinkiewcz, C. A., DiBerto, J. F., Cogan, E. S., McElligott, Z. A., \& Kash, T. L. (2020). Chronic intermittent ethanol exposure dysregulates a GABAergic microcircuit in the bed nucleus of the stria terminalis. Neuropharmacology, 168, 107759. 
Pati, D., Pina, M. M., \& Kash, T. L. (2019). Ethanol-induced conditioned place preference and aversion differentially alter plasticity in the bed nucleus of stria terminalis. Neuropsychopharmacology, 44(11), 1843-1854.

Pinel, J. P., \& Treit, D. (1978). Burying as a defensive response in rats. Journal of Comparative and Physiological Psychology, 92(4), 708.

Potter, D. N., Damez-Werno, D., Carlezon Jr, W. A., Cohen, B. M., \& Chartoff, E. H. (2011). Repeated exposure to the $\mathrm{K}$-opioid receptor agonist salvinorin A modulates extracellular signal-regulated kinase and reward sensitivity. Biological psychiatry, 70(8), 744-753.

Poulin, J. F., Arbour, D., Laforest, S., \& Drolet, G. (2009). Neuroanatomical characterization of endogenous opioids in the bed nucleus of the stria terminalis. Progress in Neuro-Psychopharmacology and Biological Psychiatry, 33(8), 1356-1365.

Ribeiro-Carvalho, A., Lima, C. S., Nunes-Freitas, A. L., Filgueiras, C. C., Manhães, A. C., \& Abreu-Villaça, Y. (2011). Exposure to nicotine and ethanol in adolescent mice: effects on depressive-like behavior during exposure and withdrawal. Behavioural brain research, 221(1), 282-289.

Rose, J. H., Karkhanis, A. N., Chen, R., Gioia, D., Lopez, M. F., Becker, H. C., ... \& Jones, S. R. (2016). Supersensitive kappa opioid receptors promotes ethanol withdrawal-related behaviors and reduce dopamine signaling in the nucleus accumbens. International Journal of Neuropsychopharmacology, 19(5).

Sey, N. Y., Gómez-A, A., Madayag, A. C., Boettiger, C. A., \& Robinson, D. L. (2019). Adolescent intermittent ethanol impairs behavioral flexibility in a rat foraging task in adulthood. Behavioural brain research, 373, 112085.

Sher, K. J. (1987). Stress response dampening. Psychological theories of drinking and alcoholism, 227271.

Sidhu, H., Kreifeldt, M., \& Contet, C. (2018). Affective disturbances during withdrawal from chronic intermittent ethanol inhalation in C57BL/6J and DBA/2J male mice. Alcoholism: Clinical and Experimental Research, 42(7), 1281-1290.

Valdez, G. R., \& Harshberger, E. (2012). Kappa opioid regulation of anxiety-like behavior during acute ethanol withdrawal. Pharmacology Biochemistry and Behavior, 102(1), 44-47.

Varlinskaya, E. I., Johnson, J. M., Przybysz, K. R., Deak, T., \& Diaz, M. R. (2020). Adolescent forced swim stress increases social anxiety-like behaviors and alters kappa opioid receptor function in the basolateral amygdala of male rats. Progress in Neuro-Psychopharmacology and Biological Psychiatry, 98, 109812.

Walker, B. M., Valdez, G. R., McLaughlin, J. P., \& Bakalkin, G. (2012). Targeting dynorphin/kappa opioid receptor systems to treat alcohol abuse and dependence. Alcohol, 46(4), 359-370.

Walker, D. L., \& Davis, M. (2008). Role of the extended amygdala in short-duration versus sustained fear: a tribute to Dr. Lennart Heimer. Brain Structure and Function, 213(1-2), 29-42.

Wills, T. A., Klug, J. R., Silberman, Y., Baucum, A. J., Weitlauf, C., Colbran, R. J., .. \& Winder, D. G. (2012). GluN2B subunit deletion reveals key role in acute and chronic ethanol sensitivity of glutamate synapses in bed nucleus of the stria terminalis. Proceedings of the National Academy of Sciences, 109(5), E278-E287. 
Wilson, J., Watson, W. P., \& Little, H. J. (1998). CCKB antagonists protect against anxiety-related behaviour produced by ethanol withdrawal, measured using the elevated plus maze. Psychopharmacology, 137(2), 120-131.

Yilmaz, M., \& Meister, M. (2013). Rapid innate defensive responses of mice to looming visual stimuli. Current Biology, 23(20), 2011-2015. 

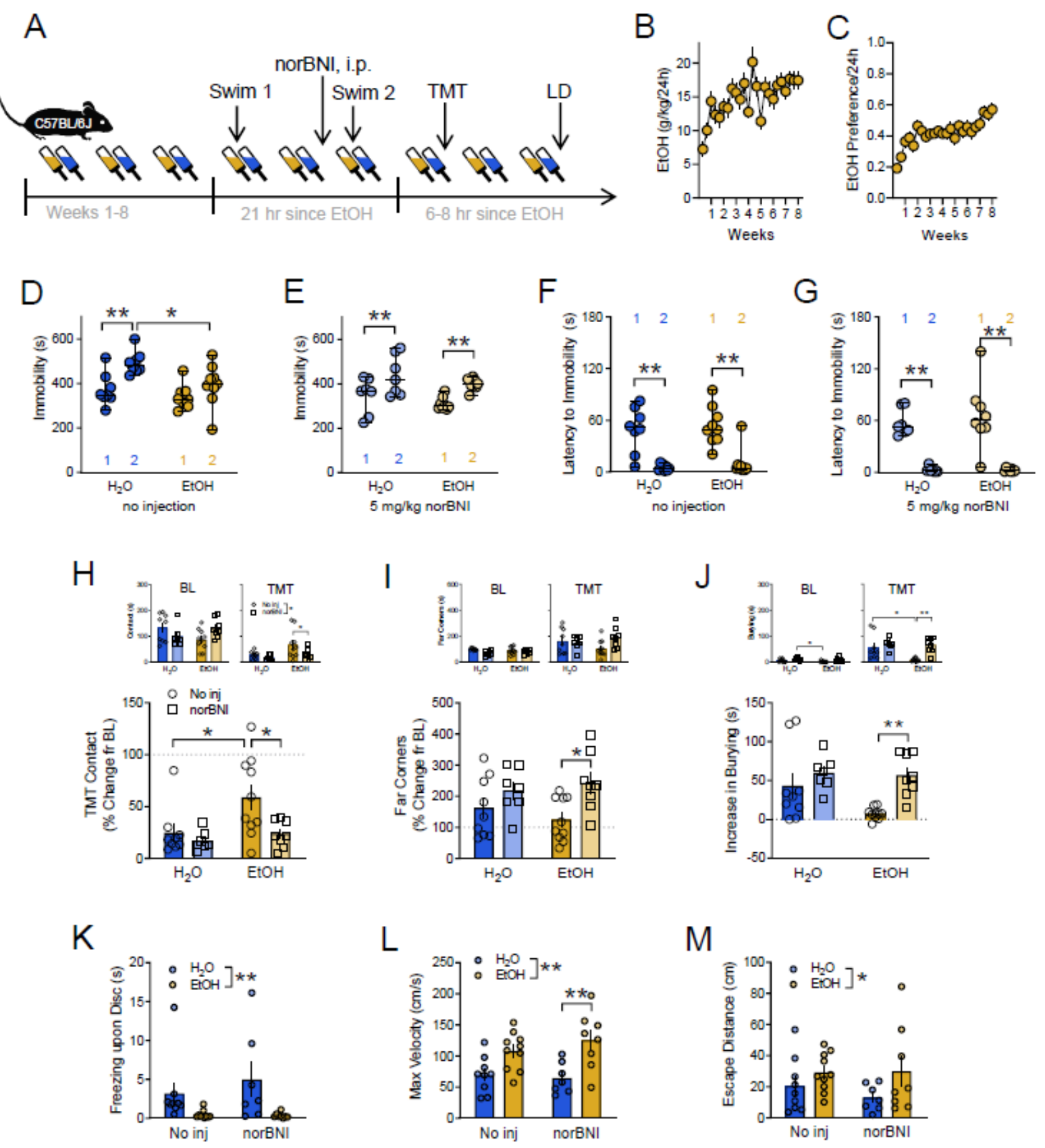

Figure 1 | Kappa opioid receptor regulation of alcohol-related responses to repeated swim test and predator odor. A| Experimental timeline of male C57BL/6J mice given two-bottle choice, intermittent EtOH for 8 weeks before stress testing in the repeated swim test, exposure to TMT predator odor, and an overhead looming disc. Long-lasting KOR antagonist norBNI was injected $16 \mathrm{hr}$ before the second swim test. B $\mathrm{EtOH}$ consumption $(\mathrm{g} / \mathrm{kg} / 24 \mathrm{~h})$ and $\mathbf{C} \mid \mathrm{EtOH}$ preference ratio / $24 \mathrm{~h}$ across 8 weeks. D| Duration of immobility (s) across two forced swim trials 
in $\mathrm{H}_{2} \mathrm{O}$-drinking (blue) and EtOH-drinking (gold) mice. Median \pm range are displayed. $\mathrm{E}$ Immobility (s) across repeated forced swim trials in norBNI-pretreated $\mathrm{H}_{2} \mathrm{O}$ (light blue) and $\mathrm{EtOH}$ (peach) mice. $\mathbf{F} \mid$ Latency to immobility (s) across swim trials and $\mathbf{G} \mid$ after norBNI treatment. In a home cage TMT exposure, percent change from baseline $\mathbf{H}$ | contact time with the TMT (s), I| time spent in the far corners (s), and $\mathbf{J} \mid$ burying duration (s) in non-injected mice (circles) and norBNI-injected mice (squares). Mean \pm SEM are displayed. Inset graphs are the raw durations (s) of behaviors during the 10 min baseline with the object (left panels) and during the 10 min TMT test (right panels). In reaction to the looming disc, $\mathbf{K}$ | freezing behavior (s), L| maximum velocity $(\mathrm{cm} / \mathrm{s})$ of the dart, and $\mathbf{M}$ | escape distance $(\mathrm{cm})$ to the hut were assessed in $\mathrm{H}_{2} \mathrm{O}$ (blue) and $\mathrm{EtOH}$ (gold) mice. ${ }^{*} \mathrm{p}<0.05 .{ }^{* *} \mathrm{p}<0.01$. 